Western North American Naturalist 69(4), ( 2009, pp. 459-468

\title{
ESTIMATING ROOT BIOMASS AND DISTRIBUTION AFTER FIRE IN A GREAT BASIN WOODLAND USING CORES AND PITS
}

\author{
Benjamin M. Rau ${ }^{1,2}$, Dale W. Johnson ${ }^{1}$, Jeanne C. Chambers ${ }^{3}$, Robert R. Blank ${ }^{4}$, and Annmarie Lucchesi ${ }^{1}$
}

\begin{abstract}
Quantifying root biomass is critical to an estimation and understanding of ecosystem net primary production, biomass partitioning, and belowground competition. We compared 2 methods for determining root biomass: a new soil-coring technique and traditional excavation of quantitative pits. We conducted the study in an existing Joint Fire Sciences demonstration area in the central Great Basin. This area is representative of a shrub (sagebrush) ecosystem exhibiting tree (pinyon and juniper) encroachment. The demonstration area had a prescribed burn implemented 4 years prior to our study, and we sampled both control and burned plots. The samples were stratified across 3 microsites (interspace, under shrub, and under tree) and 4 soil depths $(0-8,8-23,23-38$, and $38-52 \mathrm{~cm})$ to determine the effects of plant life form and burning on root biomass. We found that estimates of total root biomass were similar between quantitative pits and our soil cores. However, cores tended to show a more even distribution of root biomass across all microsites and depths than did pits. Overall, results indicated that root biomass differs significantly among microsites and soil depths and that the amount of root biomass at a given depth differs among microsites. Burning reduced root biomass in our study by $23 \%$ and altered the spatial distribution of root mass.
\end{abstract}

Key words: belowground biomass, pinyon pine, sagebrush, fire.

Quantifying root biomass is critical to an estimation and understanding of ecosystem net primary production, biomass partitioning, belowground competition, and even carbon storage. In heterogeneous landscapes, such as arid and semiarid shrublands exhibiting tree encroachment, quantifying root biomass is necessary for understanding the changes that occur in belowground biomass as tree dominance increases. It also is necessary for understanding the effects of both natural and managed fire on ecosystem carbon storage. Little data exists on root biomass, mostly because of the difficulty in making accurate measurements. The 2 most common methods are excavation of large soil pits and extraction of soil cores.

Excavating soil pits is a labor-intensive process but has been used to quantify soil-nutrient and biomass pools. Excavating vertical wall pits can be especially challenging when sampling rocky soils (Hamburg 1984, Johnson et al. 1991). The pit method suffers from the assumption that estimates of soil bulk density taken from small samples are applicable to the entire soil regolith, which may contain large rock fragments. Estimating the pit's total volume is difficult because of large rocks intruding into the side of the pit. Alternative methods for measuring pit volume have been suggested, such as filling pits with ping-pong balls, sand, or water, but each has limitations. Supplying a large volume of water is extremely difficult in remote or difficult-to-access areas. The same is true for sand. Ping-pong balls are lighter and easier to transport, but may be difficult to level at the soil surface or on slopes, and may not pack uniformly. With quantitative pits, frequently the entire monolith is not sampled due to the extensive effort and cost. Consequently, a large error is introduced into estimates by the necessity of processing subsamples, making moisture corrections to field measurements, and performing extensive backcalculations to obtain pit volume and root biomass. These measurements are not particularly complex but assume that subsamples are uniform and can be extrapolated to the entire pit.

Soil cores have received limited use in measuring root biomass because of the devices currently available for coring. Traditionally, coring devices were large truck-mounted impact or rotary tools that were not able to access

\footnotetext{
${ }^{1}$ Department of Natural Resources and Environmental Science, University of Nevada, Reno, 1000 Valley Road, Reno, NV 89512.

2E-mail: brau@unr.nevada.edu

${ }^{3}$ USDA Forest Service-Rocky Mountain Research Station, 920 Valley Road, Reno, NV 89512

${ }^{4}$ USDA Agricultural Research Service, 920 Valley Road, Reno, NV 89512.
} 


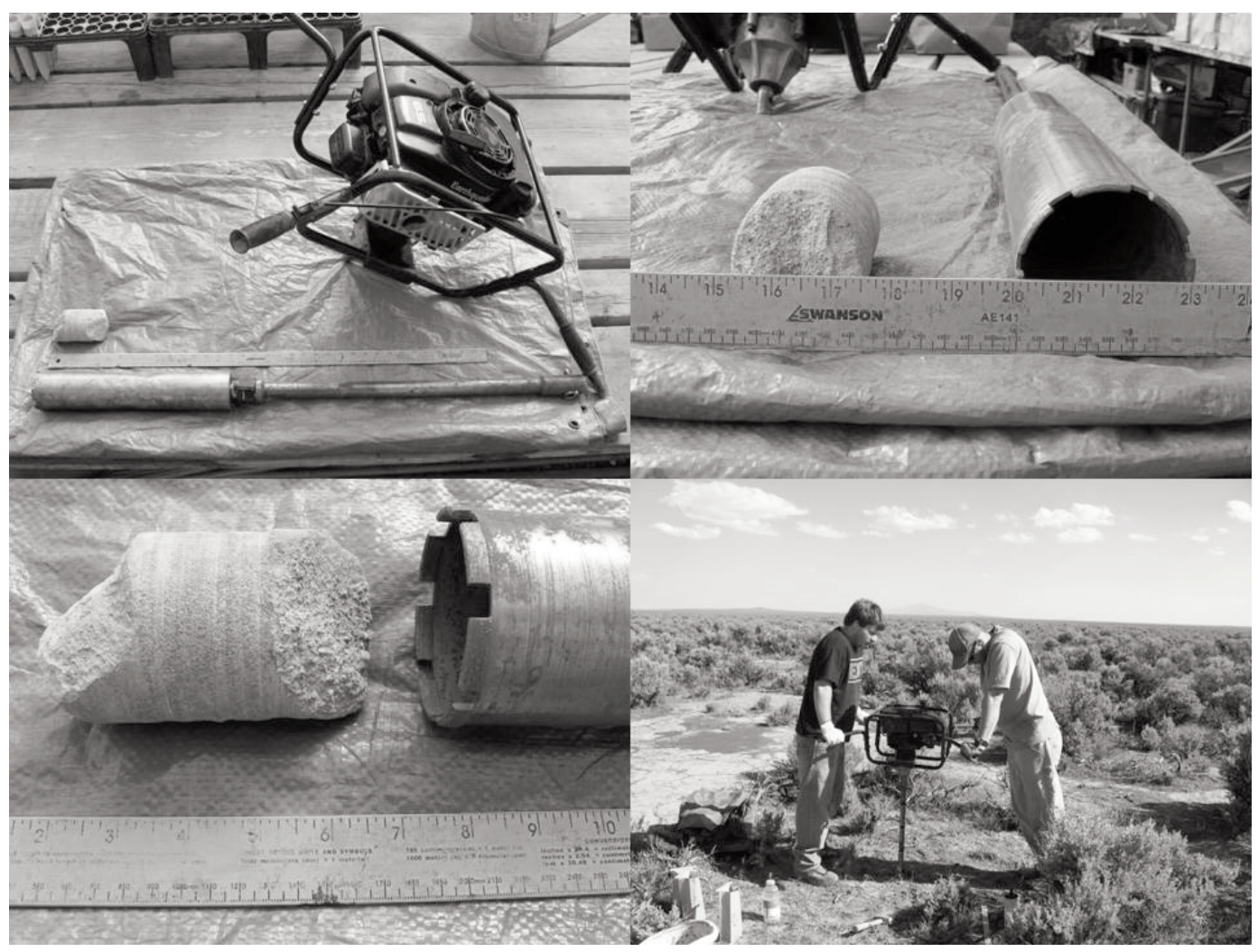

Fig. 1. Photos of the rotary core bit, the adapter shaft used to connect it to the power head, and the power head. Note how cleanly the large coarse fragment has been cut by the core device. On the rulers, the top scale is in inches and the bottom scale is in centimeters. Models are J.J. Klima and the first author at USFWS Hart Mountain Wildlife Refuge, Oregon.

remote locations, or they were small handdriven hollow rods that could not be used to collect large-diameter roots and could not penetrate past large coarse fragments (Vogt and Persson 1991). For this study, we chose a newer soil-coring device (Ponder and Alley 1997, Don Todd, USDOE Oak Ridge National Laboratory, personal communication), which utilizes a diamond-tipped rotary core drill designed for reinforced concrete applications, coupled to a 6.5-horsepower, 2-person rotary power head that delivers 120 foot-pounds of torque at the output (Fig. 1). This device allows for relatively easy sampling of rocky soils and removes most large roots and rocks in its path (Fig. 1).

This study was part of a Joint Fire Sciences demonstration project designed to examine the use of prescribed fire as a tool to slow encroachment of pinyon and juniper trees and maintain sustainable sagebrush ecosystems. Our objectives were to (1) test the new soil-coring device and compare our results with traditional soil-pit methods and (2) determine if prescribed burning has an effect on the distribution of root biomass.

\section{Methods}

Experimental Area

The Underdown Canyon study site is a Joint Fire Sciences Program demonstration area in the Shoshone Mountain Range on the Humboldt-Toiyabe National Forest (Austin Ranger District) in Nye and Lander counties, Nevada. Underdown Canyon $\left(39^{\circ} 15^{\prime} 11^{\prime \prime} \mathrm{N}\right.$, $\left.117^{\circ} 35^{\prime} 83^{\prime \prime} \mathrm{W}\right)$ is oriented east to west and varies in elevation from 2072 to $2346 \mathrm{~m}$. Average annual precipitation ranges from $23 \mathrm{~cm}$ at the bottom to $50 \mathrm{~cm}$ at the top of the drainage and arrives mostly as winter snow and spring rain. Average annual temperature recorded in Austin, Nevada (35 miles from the site), ranges 


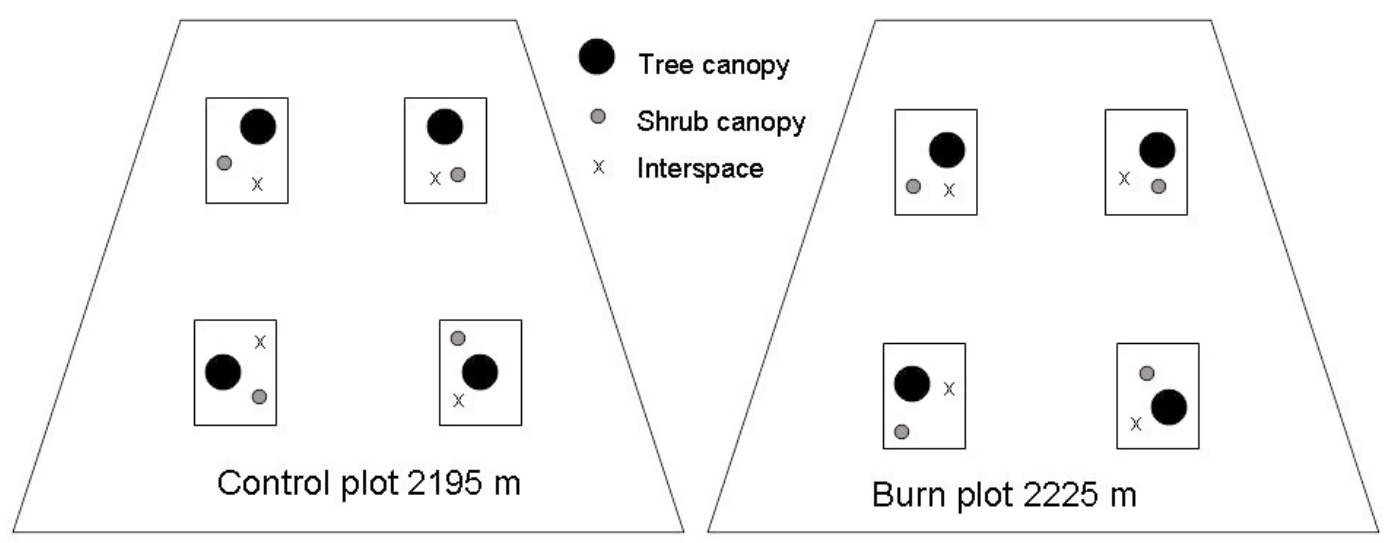

Horizontal distance between control and burn plots is approximately $750 \mathrm{~m}$

Fig. 2. Diagram depicting the 2 treatment plots, 8 subplots, and 3 microsites within the study area.

from $-7.2{ }^{\circ} \mathrm{C}$ in January to $29.4{ }^{\circ} \mathrm{C}$ in July. Lithology of the Shoshone range consists of welded and nonwelded silica ash-flow tuff. Soils are classified as coarse loamy mixed frigid Typic Haploxerolls (Rau et al. 2005). The soils are extremely coarse grained and have weak to moderate structure.

Vegetation is characterized by sagebrush (Artemisia tridentata vaseyana) and single-leaf pinyon (Pinus monophylla) with lesser cover of Utah juniper (Juniperus osteosperma). Herbaceous species include grasses (Poa secunda secunda J. Presl, Elymus elymoides Swezey, Stipa comata Trin. \& Rupr., Festuca idahoensis Elmer, and Pseudoroegneria spicata [Pursh] A. Löve) and forbs (Eriogonum umbellatum Torr., Eriogonum ovalifolium Nutt., Eriogonum elatum Dougl. ex Benth., Eriogonum heracleoides Nutt., Crepis acuminata Nutt., Phlox longifolia Nutt., Agoseris glauca [Pursh] Raf., Lupinus argenteus Pursh, and Penstemon spp). Bromus tectorum, a common invasive annual grass in the region, is not a large component of the study area. The vegetation occurs in patches of variable tree dominance typical of intermediate-age-class woodlands in the central Great Basin, and it ranges from low (12\% cover) to high tree dominance (74\% cover; Reiner 2004).

\section{Study Design and Data Collection}

Two approximately 4-ha treatment plots were established in summer 2001 on northeast-facing alluvial fans at elevations of $2195 \mathrm{~m}$ and $2225 \mathrm{~m}$. The plot at $2195 \mathrm{~m}$ was an unburned control, and the plot at $2225 \mathrm{~m}$ received a spring burn treatment. Four 0.1-ha subplots were evenly distributed in both control and burn plots and contained a mix of trees (20\% cover), shrubs (34\% cover), and interspaces (46\% cover; Fig. 2). Percent surface cover by microsite was measured using three $30-\mathrm{m}$ line-intercept transects on each replicate plot (Elzinga et al. 1998). Soil pits were dug at each microsite to a depth of $100 \mathrm{~cm}$, and the soil horizons were identified. Depth increments for sampling included the approximate depth of the soil $\mathrm{A}_{1}$ horizon and subsequent $15-\mathrm{cm}$ increments $(0-8,8-23,23-38$, and $38-52 \mathrm{~cm})$. The final increment ending at $52 \mathrm{~cm}$ was chosen because it corresponded with the transition to the $\mathrm{C}$ horizon, which is dominated by large alluvial material.

USDA Forest Service fire personnel burned the treatment plots on 11-14 May 2002 (air temperature $<32{ }^{\circ} \mathrm{C}, \mathrm{RH}>15 \%$, wind speed $<9 \mathrm{~m} \cdot \mathrm{s}^{-1}$, and gravimetric fuel moisture approximately $40 \%$ ). Because soil and fuel moisture were relatively high during burning, the vegetation and duff were consumed in patches, creating a landscape of burned and unburned islands. Fire behavior during the prescribed burn was characterized by creeping ground fire with individual and group tree torching. Some short crown runs were also observed. Sustained crown runs were not frequent due to low wind speeds and discontinuous fuels.

\section{Soil Pits}

For this study, 8 total subplots were sampled to collect root biomass: 4 each on the 


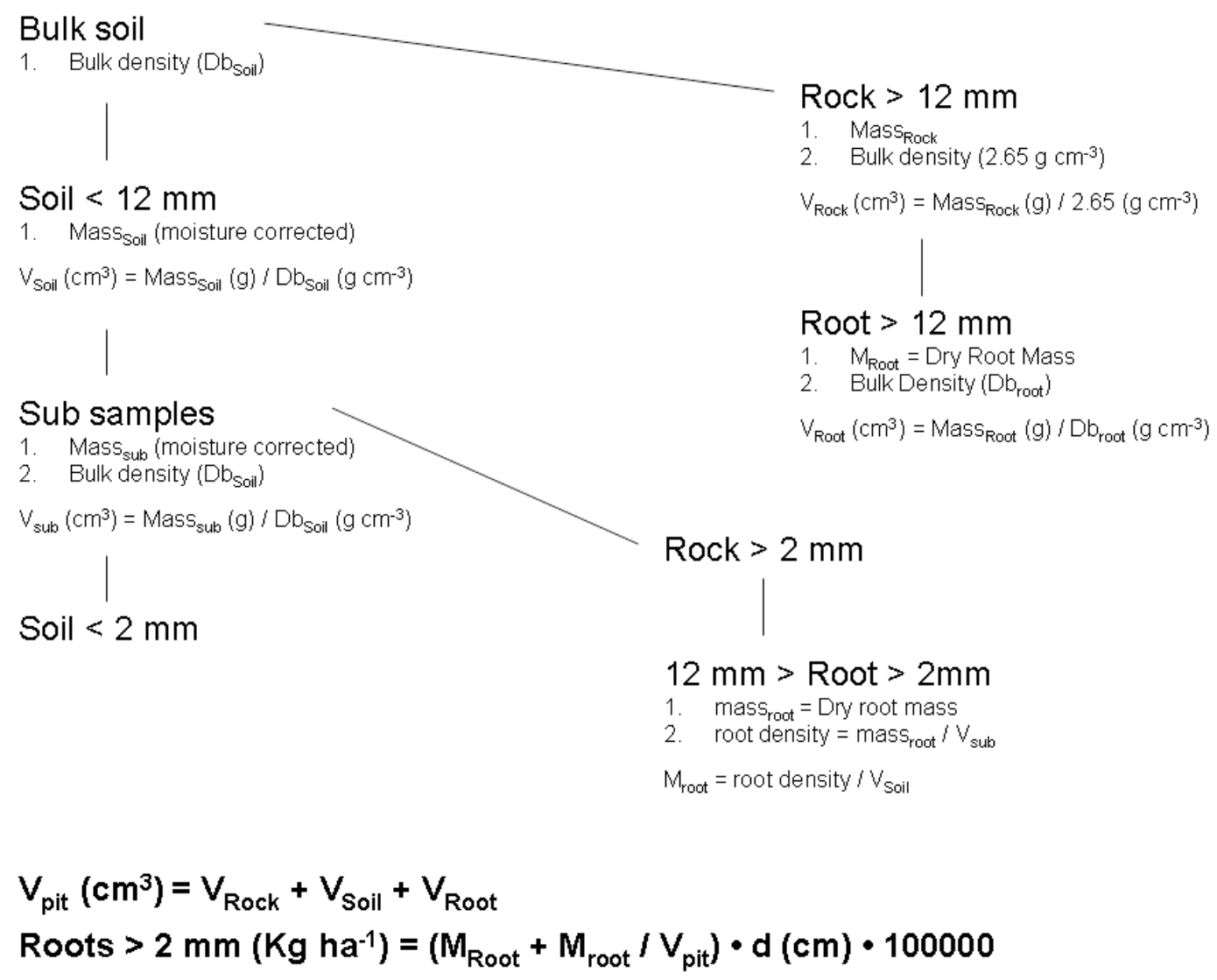

Fig. 3. Flow diagram of the quantitative soil-pit method and the process used to calculate root biomass estimates.

control and treatment sites in fall 2005 (Fig. 2). Twenty-four total soil pits were excavated: 1 at each of 3 microsites (interspace, under shrub, and under tree) within each subplot on both the control and treatment plots (Fig. 2). Pits were located $1 \mathrm{~m}$ from tree boles (under tree), centered on shrub boles (under shrub), and evenly spaced between shrubs and trees (interspace). Individual pits measured $50 \times 50 \times 52$ $\mathrm{cm}$ and were excavated in 4 consecutive depth increments $(0-8,8-23,23-38$, and $38-52 \mathrm{~cm})$, for a total of 96 samples. A $100-\mathrm{cm}^{3}$ bulk-density sample was collected from each of the 4 depth increments using an impact sampler, and all material from each depth increment was removed from pits and sieved to $12 \mathrm{~mm}$. Roots were manually separated from rocks $>12 \mathrm{~mm}$. The soil and rock fractions were weighed in the field using a Pesola ${ }^{\circledR}$ spring scale.

Subsamples of $<12$-mm soil weighing approximately $2 \mathrm{~kg}$ each were collected from each depth increment using a metal scoop.
Subsamples were returned to the lab, weighed, sieved to $2 \mathrm{~mm}$, and separated (roots from rocks) by flotation. Roots were then dried at $60{ }^{\circ} \mathrm{C}$ for 24 hours or until they no longer lost mass, and a final weight was then recorded. The volumes of the soil subsamples were estimated using bulk-density measurements, sample masses, and moisture corrections derived from separate soil subsamples dried at $100{ }^{\circ} \mathrm{C}$ for 24 hours or until the sample no longer lost mass. Subsample volume was used to calculate root density $<12 \mathrm{~mm}$, but $>2 \mathrm{~mm}$. Root density was multiplied by the total volume of soil from each pit-depth increment to estimate total root mass $<12 \mathrm{~mm}$, but $>2 \mathrm{~mm}$. This mass was added to the root mass $>12 \mathrm{~mm}$ to obtain total root mass $>2 \mathrm{~mm}$ for each depth increment (Fig. 3). Root weights were corrected for embedded-mineral fraction by ashing samples at $500{ }^{\circ} \mathrm{C}$ for 4 hours.

Total pit volume was calculated for each depth increment by adding the estimated 


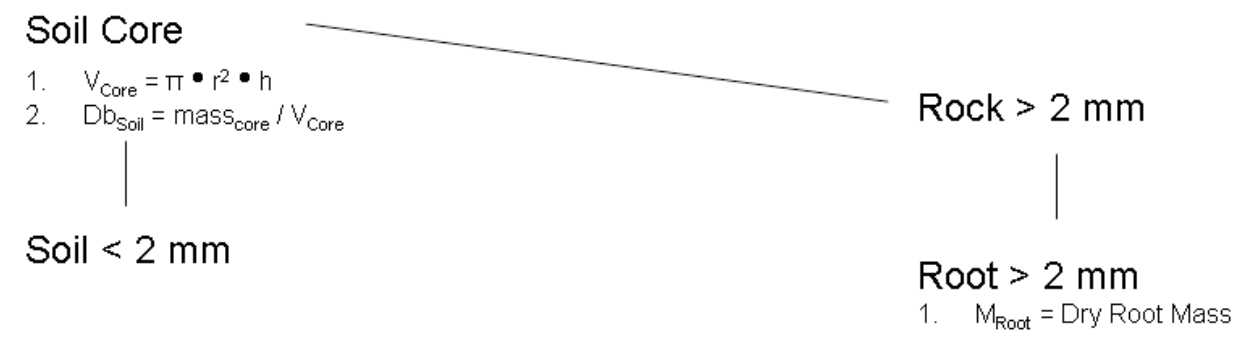

\section{Roots $>2 \mathrm{~mm}\left(\mathrm{Kg} \mathrm{ha}^{-1}\right)=\left(\mathrm{M}_{\text {Root }} / \mathrm{V}_{\text {core }}\right) \cdot \mathrm{d}(\mathrm{cm}) \cdot 100000$}

Fig. 4. Flow diagram of the soil-core method and the process used to calculate root biomass estimates.

$>12$-mm rock volume $(>12-\mathrm{mm}$ rock mass $/ 2.60$ $\left.\mathrm{g} \cdot \mathrm{cm}^{-3}\right)$, the $<12-\mathrm{mm}$ soil volume $(<12-\mathrm{mm}$ soil mass moisture corrected $\left./ \mathrm{Db}_{\text {soil }}\right)$, and the $>12-\mathrm{mm}$ root volume $(>12-\mathrm{mm}$ dry root mass $/ \mathrm{Db}_{\text {root }}$ ).

\section{Soil Cores}

Twenty-four soil cores were extracted, one at each microsite (interspace, under shrub, and under tree) on each subplot on control and treatment plots, using a method similar to the one described by Ponder and Alley (1997). The method utilizes a 7.62-cm-diameter diamond-tipped core device manufactured by Diteq $^{\mathrm{TM}}$ and driven by a 2-person, rotary Briggs and Stratton ${ }^{\mathrm{TM}}$ power head, allowing it to core through rocks and soil with minimal compaction (Fig. 1). This auger differs very little from the device described by Ponder and Alley (1997). However, we were able to successfully utilize the diamond-tipped core drills, which they reported as unreliable.

Four soil samples corresponding to the depth increments excavated in pits were removed from each bore hole for a total of 96 samples. Each sample increment was extracted before the core was augered to the next depth increment. This methodology was designed to help minimize compaction of each depth increment but could have resulted in some soil from upper layers being incorporated into lower cores. Cores were bagged individually, brought back to the lab, dried at $100{ }^{\circ} \mathrm{C}$ for 48 hours, and weighed. Cores were then sieved to 2 $\mathrm{mm}$, and roots were separated from rocks by flotation; cores were dried again at $60{ }^{\circ} \mathrm{C}$ and weighed to obtain total root mass $>2 \mathrm{~mm}$ for each depth increment (Fig. 4). Root weights were corrected for embedded-mineral fraction by ashing samples at $500{ }^{\circ} \mathrm{C}$ for 4 hours.

\section{Statistical Analyses}

All data were natural-log transformed to meet the assumption that the data were normally distributed. All comparisons were evaluated using SAS ${ }^{\mathrm{TM}}$ mixed-effects models. Treatment, microsite, depth, and sample-type differences were evaluated using treatment as a main effect, microsite as a split plot within treatment, depth as a split plot within treatment and microsite, and sample type as a split plot within treatment, microsite, and depth (Table 1). This overall analysis was not ideal for measuring treatment and microsite effects across the entire study area because mean values for microsite and depth do not necessarily reflect the coverage of these sample locations on the landscape. Therefore, a second set of comparisons was made using the sum of root biomass through the soil profile. To evaluate overall treatment differences on root mass, the mass calculated for each microsite was weighted by the microsite's cover percentage on the study plots. Treatment was evaluated as a main effect, microsite was a split plot within treatment, and sample type was a split plot within treatment and microsite (Table 2). Mean comparisons were made with Tukey's test $(P<0.05)$ after confirming significant main effects and interactions with the mixed models $(P<0.05)$. 
TABLE 1. Results from the mixed-effects model comparing treatment, microsite, depth, and sample type (pit vs. core).

\begin{tabular}{|c|c|c|c|}
\hline Comparison & $\mathrm{df}$ & $F$ & $P$ \\
\hline Treatment & 1 & 10.50 & 0.0177 \\
\hline Subplot (Treatment) error A & 6 & & \\
\hline Microsite & 2 & 4.23 & 0.0407 \\
\hline Treatment $\times$ Microsite & 2 & 0.39 & 0.6848 \\
\hline Microsite $\times$ Subplot $($ Treatment) error B & 12 & & \\
\hline Depth & 3 & 7.10 & 0.0004 \\
\hline Treatment $\times$ Depth & 3 & 3.56 & 0.0200 \\
\hline Microsite $\times$ Depth & 6 & 4.36 & 0.0012 \\
\hline Treatment $\times$ Microsite $\times$ Depth & 6 & 0.33 & 0.9200 \\
\hline Depth $\times$ Microsite $\times$ Subplot $($ Treatment) error $C$ & 54 & & \\
\hline Sample Type & 1 & 2.11 & 0.1532 \\
\hline Sample Type $\times$ Treatment & 1 & 2.05 & 0.1586 \\
\hline Sample Type $\times$ Microsite & 2 & 0.00 & 0.9972 \\
\hline Sample Type $\times$ Treatment $\times$ Microsite & 2 & 0.13 & 0.8752 \\
\hline Sample Type $\times$ Depth & 3 & 3.01 & 0.0392 \\
\hline Sample Type $\times$ Treatment $\times$ Depth & 3 & 1.14 & 0.3416 \\
\hline Sample Type $\times$ Microsite $\times$ Depth & 6 & 3.28 & 0.0087 \\
\hline Sample Type $\times$ Treatment $\times$ Microsite $\times$ Depth & 6 & 1.21 & 0.3195 \\
\hline Sample Type $\times$ Depth $\times$ Microsite $\times$ Subplot $($ Treatment) error D & 48 & & \\
\hline
\end{tabular}

TABLE 2. Results from the mixed-effects model comparing treatment, microsite, and sample type (pit vs. core) summed over all depth increments.

\begin{tabular}{|c|c|c|c|}
\hline Comparison & $\mathrm{df}$ & $F$ & $P$ \\
\hline Treatment & 1 & 6.61 & 0.0546 \\
\hline Subplot (Treatment) error A & 6 & & \\
\hline Microsite & 2 & 3.68 & 0.0029 \\
\hline Treatment $\times$ Microsite & 2 & 0.31 & 0.1052 \\
\hline Microsite $\times$ Subplot (Treatment) error B & 12 & & \\
\hline Sample Type & 1 & 2.45 & 0.2810 \\
\hline Sample Type $\times$ Treatment & 1 & 2.26 & 0.2243 \\
\hline Sample Type $\times$ Microsite & 2 & 0.03 & 0.9701 \\
\hline Sample Type $\times$ Treatment $\times$ Microsite & 2 & 0.13 & 0.8757 \\
\hline Sample Type $\times$ Microsite $\times$ Subplot $($ Treatment $)$ error $C$ & 12 & & \\
\hline
\end{tabular}

\section{RESULTS}

\section{Pits vs. Cores}

There was no difference between the mean values of root biomass per sample increment for soil pits $\left(2206 \mathrm{~kg} \cdot \mathrm{ha}^{-1}, s_{\bar{x}}=205\right)$ and soil cores $\left(2324 \mathrm{~kg} \cdot \mathrm{ha}^{-1} s_{\bar{x}}=171\right)$ and no difference between the sums of root biomass through the soil profile for soil pits $\left(8828 \mathrm{~kg} \cdot \mathrm{ha}^{-1}, s_{\bar{x}}=\right.$ $499)$ and soil cores (9297 $\left.\mathrm{kg} \cdot \mathrm{ha}^{-1}, s_{\bar{x}}=806\right)$. However, cores tended to show a more uniform vertical distribution of roots than pits did at each microsite measured, as indicated by the sample type $\times$ depth and sample type $\times$ microsite $\times$ depth interactions (Table 1 , Fig. 5).

\section{Spatial Distribution of Roots}

The sum of root biomass differed across microsites, with tree $\left(9878 \mathrm{~kg} \cdot \mathrm{ha}^{-1}, s_{\bar{x}}=803\right)$ and shrub $\left(9875 \mathrm{~kg} \cdot \mathrm{ha}^{-1}, s_{\bar{x}}=888\right)$ microsites having more total root biomass than interspace microsites $\left(7514 \mathrm{~kg} \cdot \mathrm{ha}^{-1}, s_{\bar{x}}=826 ; P<0.05\right.$; Table 2). Root biomass across all microsites typically decreased with depth $(P<0.05)$, but depth patterns varied by microsite, as indicated by the microsite-depth interaction (Table 1). Interspace microsites had most roots concentrated in the top $8 \mathrm{~cm}$ of soil; shrubs had most roots within the first $23 \mathrm{~cm}$, and trees concentrated root biomass in the $23-38-\mathrm{cm}$ soil layer (Fig. 6).

\section{Effect of Burning}

Burning reduced the mean mass of individual samples' increments by $23 \%$ (Table 1 ), from $2566 \mathrm{~kg} \cdot \mathrm{ha}^{-1}\left(s_{\bar{x}}=183\right)$ to $1981 \mathrm{~kg} \cdot \mathrm{ha}^{-1}$ $\left(s_{\bar{x}}=183\right)$. Burning may have also reduced root biomass through the profile by $23 \%$ (Table 2), from $10,266 \mathrm{~kg} \cdot \mathrm{ha}^{-1}\left(s_{\bar{x}}=695\right)$ to 


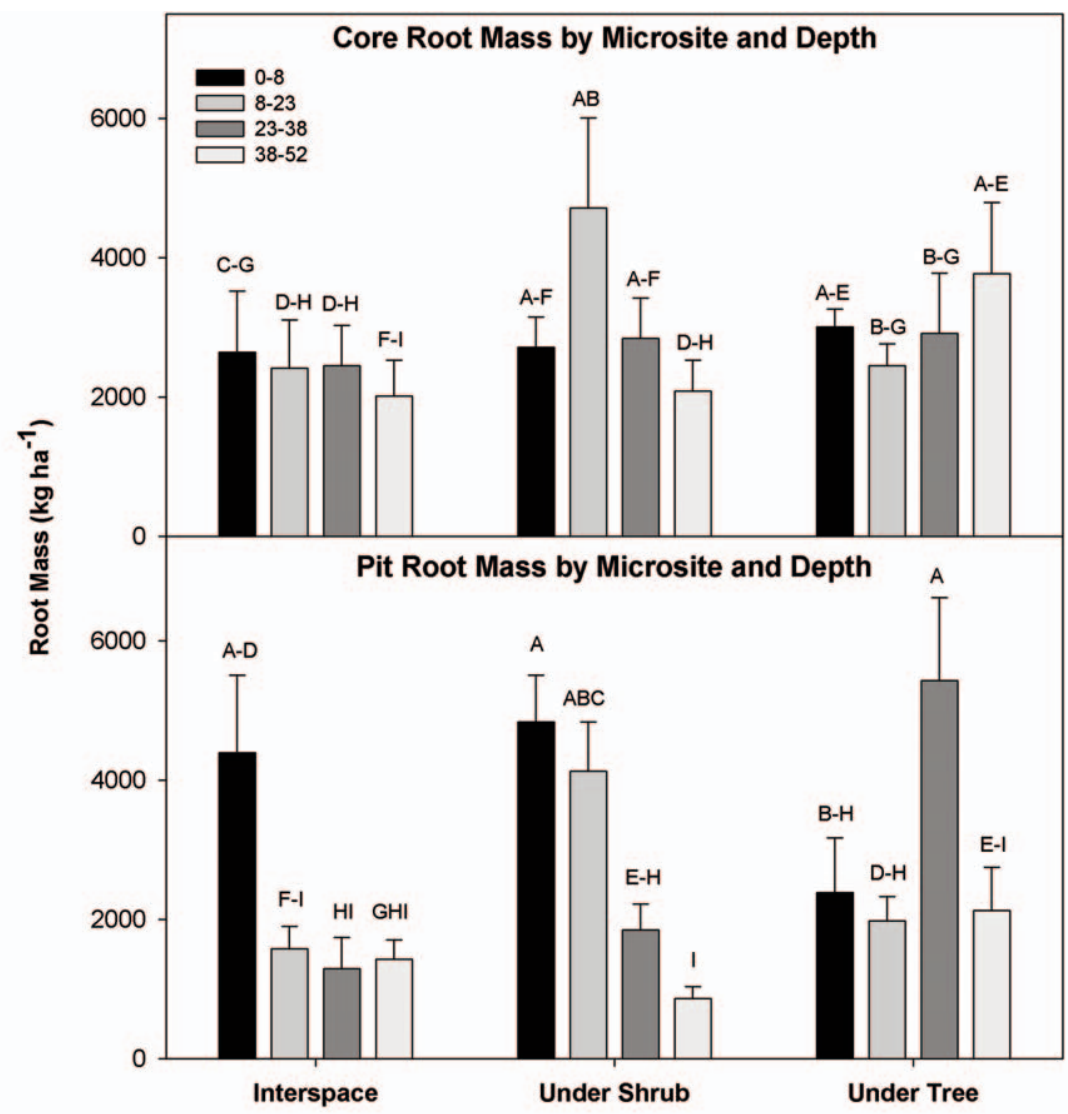

Fig. 5. Tukey's means comparison for microsite $\times$ depth $\times$ sample type interactions. Means not represented by the same letter are significantly different $(P \leq 0.05)$. Bars represent estimated $>2$-mm root biomass for 3 microsites (under tree, under shrub, and interspace), 4 soil depths $(0-8,8-23,23-38$, and $38-52 \mathrm{~cm})$, and 2 sample types (pits and cores). Means and standard errors are calculated from core and pit samples separately.

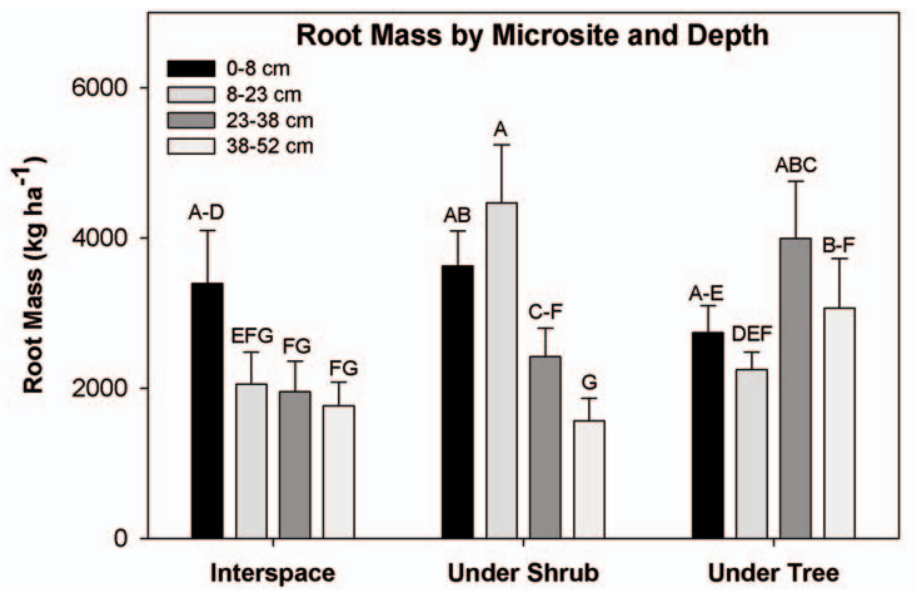

Fig. 6. Tukey's means comparison for microsite $\times$ depth interactions. Means not represented by the same letter are significantly different $(P \leq 0.05)$. Bars represent estimated $>2$-mm root biomass for 3 microsites (under tree, under shrub, and interspace) and 4 soil depths $(0-8,8-23,23-38$, and 38-52 $\mathrm{cm})$. Means and standard errors are calculated from core and pit samples combined. 


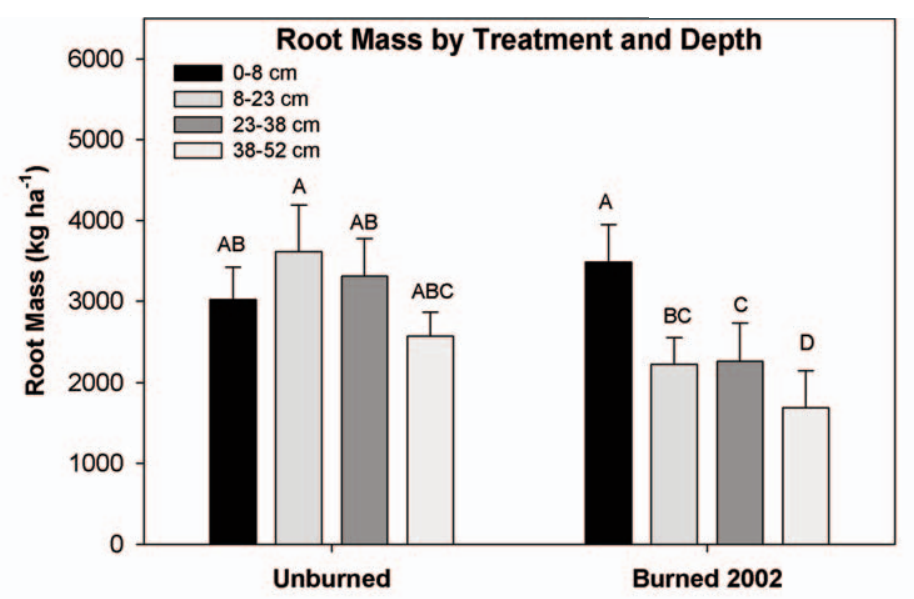

Fig. 7. Tukey's means comparison for treatment $\times$ depth interactions. Means not represented by the same letter are significantly different $(P \leq 0.05)$. Bars represent estimated $>2$-mm root biomass for 3 microsites (under tree, under shrub, and interspace), 4 soil depths (0-8, 8-23, 23-38, and 38-52 cm), and 2 treatments (control and burned). Means and standard errors are calculated from core and pit samples combined.

$7925 \mathrm{~kg} \cdot \mathrm{ha}^{-1}\left(s_{\bar{x}}=649\right)$. There was a significant treatment $\times$ depth interaction, indicating that burning reduced root mass in depths below $8 \mathrm{~cm}$ (Table 1; Fig. 7).

\section{Discussion}

\section{Pits vs. Cores}

We expected that quantitative pits and cores would provide relative indices of root biomass that were inherently different due to samplingspecific bias. The lack of difference between these 2 sampling methods at the individual sample-increment and soil-profile levels contrasts with other studies that have documented differences between methods as high as $27 \%$ (Park et al. 2007). However, our results are consistent with results reported for large intact monoliths from a shortgrass steppe in northeastern Colorado (LeCain et al. 2006).

We believe that the lack of difference between our sampling methods is due to the type of coring device used. The new device was designed to core through concrete and is well suited to soil sampling. This device will core through rock fragments, which eliminates problems described by other researchers who were unable to push a simple punch core through coarse fragments and large-diameter roots (Vogt and Presson 1991). The device is also small enough that it can be transported into rugged terrain, unlike truck-mounted units.
Because it unbiasedly cores though rock, roots, and soil, this device also should yield a more accurate estimate of sample volume and whole-soil bulk density. Some researchers have reported increases in bulk density using traditional cores and have ascribed those increases to compaction of the sample (Vogt and Persson 1991). However, Ponder and Alley (1997) reported no increase in soil bulk density when using a device similar to the one we employed. Some compaction of the sample may have occurred with the new device, increasing whole-soil bulk density, but it is likely that a more proportionate (larger) volume of large coarse fragments was sampled because the diamond-tipped bit cuts cleanly through these fragments. Because large coarse fragments have a mean bulk density of $2.6 \mathrm{~g}$. $\mathrm{cm}^{-3}$, the bulk density of the samples was probably increased compared to that of studies using traditional impact cores, which require some coarse fragments to be excluded.

Our higher-level interactions for sample type $\times$ depth, and sample type $\times$ depth $\times$ microsite show a significant influence of the sample method on root mass. Soil pits typically show much larger variability across depths and microsites, while soil cores indicate a more even distribution across depths and microsites. We attribute this discrepancy to having sample areas that are unique to each method. A soil core is only $7.62 \mathrm{~cm}$ in diameter, giving it an area of $45.6 \mathrm{~cm}^{2}$. A soil pit measured $50 \mathrm{~cm}$ 
on a side, giving it an area of $2500 \mathrm{~cm}^{2}$. Thus, for a given depth, a pit samples an area 55 times larger than a core. Further investigation is necessary to determine how the area sampled affects estimates of root distribution on the landscape. A smaller sample area will have a larger edge effect, where roots may be included or excluded from the sample if they are not cut cleanly at the sample margins. This variability could increase the error associated with root biomass estimates.

The coring method modified from Ponder and Alley (1997) shows significant promise for streamlining belowground biomass sampling and sample processing. Quantitative soil pits can take as long as 3 hours to excavate depending on the depth obtained and the number of large coarse fragments encountered. Pits also require transportation of large sieves, tarps, buckets, scales, and excavation tools. Heavy equipment may be necessary to excavate and extricate monoliths. In addition to increased field time, quantitative pits require processing of moisture samples and soil subsamples, as well as computation time (Fig. 3). By contrast, a soil core can typically be extracted in less than a half hour. The core device does require similar amounts of equipment, but it can be easily transported by 3 people into remote areas that cannot be accessed with large equipment. Sample processing and data calculations for core samples are considerably simpler than those for quantitative pits, and these simpler procedures reduce the possibility for error (Fig. 4). The core device can be assembled for approximately $\$ 1200$ USD utilizing currently available products and materials common at most metal fabricators. We believe the core gives more accurate estimates of sample volume, rock fragment, and bulk density than previously utilized methods. This method should allow researchers to use larger sample sizes over a broader range of soil conditions and should improve estimates of belowground biomass. Additional consideration should be given to the effect of core diameter on estimated root distribution, and it would be worthwhile to make further comparisons of pits and cores across more locations and ecosystems.

\section{Spatial Distribution of Roots}

Cold deserts have some of the most extensive belowground biomass of any ecosystem (Jackson et al. 1996). However, the spatial distribution of roots in arid sagebrush ecosystems has been documented infrequently over the last century, and studies typically have focused on a single plant species, particularly sagebrush (Robertson 1943, Frischknecht 1963, Sturges 1977, Richards and Caldwell 1987). Our data show that both the distribution and amount of belowground root biomass may change with conversion from grassland to woodland by succession or from woodland to grassland by fire.

Tree and shrub microsites typically had greater root biomass in the top $50 \mathrm{~cm}$ of the soil profile than did interspace microsites. We suspect that root mass is concentrated beneath trees and shrubs, but it is likely these roots are spreading laterally into areas without tree or shrub cover. Sturges (1977) observed that sagebrush produced lateral roots extending over $1 \mathrm{~m}$ from the shrub bole. It is likely that pinyon pine and juniper have roots which extend even farther laterally (Kramer et al. 1996).

Our data show that herbaceous vegetation found in interspace had most of its root mass in surface horizons $(0-8 \mathrm{~cm})$. Similarly, sagebrush in this study tended to maximize root density near the surface, but it also partitioned large amounts of root mass just below the surface $(8-23 \mathrm{~cm})$. We also observed that shrubs had a long taproot extending well into the soil profile, at least to the bottoms of our pits. Finally, trees tended to have maximum root density near the subsurface $(23-52 \mathrm{~cm})$ or lithic contact. This pattern has been noted by other researchers in arid environments and has been linked to high soil carbon content at depth in mature woodlands (McDaniel and Graham 1992). Trees tended to have the lowest root density near the surface $(0-8 \mathrm{~cm})$, which is typical of trees growing in semiarid regions with low summer precipitation (Williams and Ehleringer 2000).

\section{Effect of Burning}

Burning resulted in a statistically significant reduction in root biomass measured to 52 $\mathrm{cm} 4$ years afterward. However, the absolute magnitude of the reduction was relatively small $(23 \%)$. What is perhaps more interesting is how burning influenced the distribution of roots. Control plots averaged across all microsites displayed a root distribution more representative of the tree and shrub microsites. Conversely, the burned site had a distribution 
representative of interspace microsites or herbaceous vegetation. The rapid change in distribution may be related to partial or complete decomposition of roots after the death of trees and shrubs and to the regrowth and establishment of herbaceous vegetation on the site. Following the burn, herbaceous vegetation on the site increased in cover, biomass, and nutrient content (Rau et al. 2008, Goergen and Chambers 2009).

\section{Conclusions}

Estimates of root biomass using quantitative pits were similar to estimates of root biomass using soil cores; however, pits yielded higher variability in spatial distributions and burn effects. We believe that the area of each sample type influences these results, possibly due to edge effects. More work is needed to better understand how sample area influences root biomass estimates.

Root biomass was higher under tree and shrub canopies than in interspaces. Also, root biomass was highest near the soil surface at interspace and undershrub microsites and decreased with depth. However, root biomass was concentrated near the lithic contact under tree canopies.

Burning appeared to reduce root biomass on the plots and alter the distribution of roots so that profiles of burned plots become more similar to profiles observed at interspace microsites.

\section{Literature Cited}

Elzinga, C.L., D.W. Salzer, and J.W. Willoughby. 1998. Field techniques for measuring vegetation. Pages 159-205 in Measuring and monitoring plant populations. Bureau of Land Management, Denver, CO.

FrischKNECHT, N.C. 1963. Contrasting effects of big sagebrush and rubber rabbitbrush on production of crested wheatgrass. Journal of Range Management 16:70-74.

Goergen, E.M., AND J.C. Chambers. 2009. Influence of a native legume on soil $\mathrm{N}$ and plant response following prescribed fire in sagebrush steppe. International Journal of Wildland Fire 18:665-675.

Hamburg, S.P. 1984. Effects of forest growth on soil nitrogen and organic matter pools following release from subsistence agriculture. Pages 145-158 in E.L. Stone, editor, Forest soils and treatment impacts. Proceedings of the North American Forest Soils Conference. University of Tennessee, Knoxville.

Jackson, R.B., J. Canadell, J.R. Ehleringer, H.A. Mooney, O.E. Sala, and E.D. Schulze. 1996. A global analysis of root distributions for terrestrial biomes. Oecologia 108:389-411.

Johnson, C.E., A.H. Johnson, T.G. Huntington, And T.G. SICCAMA. 1991. Whole-tree clear cutting effects on soil horizons and organic-matter pools. Soil Science Society of America Journal 55:497-502.

Lecain, D.R., J.A. Morgan, D.G. Milchunas, A.R. Mosier, J.A. Nelson, And D.P. Smith. 2006. Root biomass of individual species, and root size characteristics after five years of $\mathrm{CO}_{2}$ enrichment on native shortgrass steppe. Plant and Soil Journal 279: 219-228.

Kramer, S., P.M. Miller, and L.E. Eddleman. 1996. Root system morphology and development of seedling and juvenile Juniperus occidentalis. Forest Ecology and Management 86:229-240.

McDaniel, P.A., And R.C. Graham. 1992. Organic carbon distributions in shallow soils of pinyon-juniper woodlands. Soil Science Society of America Journal 56:499-504

Park, B.B., R.D. Yanai, M.A. Vadebocoeur, and S.P. HambURG. 2007. Estimating root biomass in rocky soils using pits, cores, and allometric equations. Soil Science Society of America Journal 71:206-213.

Ponder, F., AND D.E. Alley. 1997. Soil sampler for rocky soils. Research Note NC-371, USDA Forest Service, North Central Forest Experiment Station, St. Paul, $\mathrm{MN}$.

RaU, B.M., J.C. Chambers, R.R. BLANK, AND D.W. JoHnSON. 2008. Prescribed fire, soil, and plants: burn effects and interactions in the central Great Basin. Rangeland Ecology and Management 61:169-181.

RaU, B.M., J.C. Chambers, R.R. Blank, AND W.W. Miller. 2005. Hydrologic response of a central Nevada pinyon-juniper woodland to prescribed fire. Rangeland Ecology and Management 56:614-622.

Reiner, A.L. 2004. Fuel load and understory community changes associated with varying elevation and pinyon-juniper dominance. Master's thesis, University of Nevada, Reno.

Richards, J.H., AND M.M. Caldwell. 1987. Hydraulic lift: substantial nocturnal water transport between soil layers by Artemisia tridentata roots. Oecologia 73:486-489.

Robertson, J.H. 1943. Seasonal development of sagebrush (Artemisia tridentata Nutt.) in relation to range reseeding. Ecology 24:125-126.

Sturges, D.L. 1977. Soil water withdrawal and root characteristics of big sagebrush. American Midland Naturalist 88:257-274.

Vogt, K.A., And H. Persson. 1991. Measuring growth and development of roots. Pages 447-501 in J.P. Lassoie and T.M. Hinckley, editors, Techniques and approaches in forest tree ecophysiology. CRC Press, Boca Raton, FL.

Williams, D.G., AND J.R. Ehleringer. 2000. Carbon isotope discrimination and water relations of oak hybrid populations in southwestern Utah. Western North American Naturalist 60:121-129.

Received 20 June 2008 Accepted 9 July 2009 